\title{
Poetry in the Social Studies Textbooks in Turkey
}

Bulent Tarman*

Independent Researcher

\section{Emin Kilinc}

Independent Researcher

*Corresponding Author: btarman@gmail.com

Received : 2018-05-14

Accepted : 2018-06-10

How to cite this paper: Tarman, B. \& Kilinc, E. (2018). Poetry in the social studies textbooks in Turkey. Journal of Culture and Values in Education, 1(1), 50-62.

\section{Abstract}

The purpose of this paper is to examine social studies textbooks to investigate the use of poetry in the social studies textbooks in Turkey. This paper also examines whose poets have been represented in the textbooks. The authors applied content analysis to evaluate social studies textbooks. Content analysis is a research method that uses a set of procedures to make valid inferences from text. It is also described as a method of analyzing written, verbal or visual communication messages. Content analysis allows the researcher to test theoretical issues to enhance understanding of the data. The results showed that very few poems were used in the social studies textbooks. The finding of the study revealed that poems in the $4^{\text {th }}$ grade textbooks relate to topics that were interest to students the nature and humanism. Poem about Şavşat, described the beauty of Turkish homeland in the four seasons. Vetch Field poem in the $5^{\text {th }}$ grade social studies textbook, described a bride who has to work in the field. This poem seems to be written for girls since the language indicates 'girls' several times. It emphasizes how hard to be a bride in the vetch field. Remaining poems were used to promote students' patriotic values. These poems emphasizes flag, homeland, heroism etc.

Keywords: Textbooks, Poems, Social Studies Education

\section{Introduction}

We are living in an ever-changing world. Globalization, massive migration, development of the technology etc. might reflect changing ideas and social practices. In attempting to respond to a variety of national and international pressures, governments have instituted seemingly endless reviews and reforms within the educational sector (Roberts, 2008; Tarman \& Dev, 2018). As Apple (2004) indicated, educational institutions are parts of public sphere. Hence, deciding what kind of knowledge should be thought is one of the primary responsibilities of National Ministry of Education in Turkey. Social studies curriculum, as well as other curricula, 
has been prepared under the surveillance by the National Ministry of Education for transmission of the dominant ideology.

From the establishment of the Republic of Turkey, all the government educational programs carried the characteristics of progressive educational movement (Gözütok, 2008). However, there are two main obstacles to apply progressive ideas: teachers and high stake testing (Tarman \& Gürel, 2017). The educational system has been continued as teacher and subject centered; textbooks are essential to equip students with the 'official knowledge'; and students have needed to learn what books write. Unfortunately, curriculum understood only institutionally as a result of this school became a mausoleum not a civic forum (Pinar, 1999). A hermeneutics of subjectivity and aesthetics empowers educators to resist methodological approaches that seek to certify inert information for canonical accountability (Slattery, 2008). The purpose of this paper is to examine social studies textbooks to investigate the use of poetry in the social studies textbooks in Turkey. This paper also examines whose poets have been represented in the textbooks. The authors applied content analysis to evaluate social studies textbooks. Content analysis is a research method that uses a set of procedures to make valid inferences from text. (Weber, 1990). It is also described as a method of analyzing written, verbal or visual communication messages (Cole, 1988). Content analysis allows the researcher to test theoretical issues to enhance understanding of the data (Elo \& Kyngas, 2008).

\section{Social Studies Education in Turkey}

Social studies is an independent course of study and involves more than memorizing factual information. Indeed, social studies promotes understanding of people, culture, and the world (Barr, 1997). The term of social studies has been first used in 1916 in the United States to the response of the press of cultural, racial, and gender differences (Crocco, 2004; Kilinc, 2012) by the National Education Association's (NEA) 1916 Committee on Social Studies (Ross, 2006; Singer, 2005). Social studies has been part of Turkish school curriculum in the late 1960's. From the announcement of the first school curricula of Turkey in 1924 to 1968, social studies were organized separately around three academic disciplines; history, geography, and civic (Tarman; 2011; 2016;2017).

From the foundation of the Republic of Turkey in 1923, education has been seen as a tool to transform and modernize Turkish society by policy makers. Therefore, the new regime, the republic, instituted a highly centralized education system that controlled general affairs relating to education such as regulating curricula and textbooks (Childress, 2001; Kazamias, 1966). The new regime aimed to modernize Turkish society and made numerous revolutions such as secularism, language reform, Latinization of the Turkish alphabet, promoting sun Language Theory that advocates almost all civilizations originated with the Turks instead of Ottoman history and Islam. In order to promote these revolutions among citizens, the new regime needed to nurture young generations as well as adults as citizens of the Republic and recognition of the new revolutions (Kilinc, Erdogan, Cavlazoglu, \& Burlbaw, 2014). Thus, school 
curricula especially history, geography, and civics were used to create nationalist, republican, and secularist citizens.

The term of social studies has been used in 1968 school curricula. Social studies aimed to promote patriotic values amongst young generations. Nationalism, secularism, patriotism, and republicanism remained in their positions in the social studies curriculum (Mauch \& Tarman, 2016; Tarman \& Acun, 2010; Tarman, 2011; Tarman \& Ayas, 2011; Yiğit \&Tarman, 2013). From 1968 to today, the social studies curriculum revised several times. The latest revision has been made in 2017. Constructivist approach has been continued to effect social studies curriculum development in Turkey. Active participation, global education, environment and human rights are seen as important characteristics of the current social studies curriculum.

The latest social studies curriculum aims to promote of civic competence and provide practicing democracy for student. Democracy does not mean only voting or political participation; but it involves civic practices besides voting. Therefore, the use of appropriate poems in the social studies extend and enhances the atmosphere surrounding more fact-laden subject areas, which can make social studies more meaningful and exciting for students (Perfect, 1999). However, poetry is solely taught in Turkish course as reading parts. There is very little space for poetry in the social studies textbooks.

\section{Poetry and Social Studies Education}

Poetry has been defined as 'a form of language that says more and says it more intensely than does ordinary language' (Arp, 1997, p.3). Dunlop (2007) describes poetry as a means of discovery. Therefore, it can be used as a teaching-learning tool in the social studies to enhance students' understanding and expand their perception of the world.

Poetry can be seen as a light in the dark times. Individuals try to resist antidemocratic regimes and social injustices through poetry. Thus, autocrats consider poetry as threatening acts for current system and attempts to silence poets. On the other hands, many scholars believed that poetry that addresses democratic practices promotes human dignity and equality among citizens (Ciardiello, 2010; Pinsky, 2007).

There are several benefits to use poetry in the teaching-learning process. For instance, the use of poetry promotes learners in making some initial reflections. In addition, the use of poetry enables learners to re-orientate and consolidate prior learning (Threlfall, 2013). Through poetry, students think abstractly (Dunlop, 2007), see differently, understand each other, and validate human experience. Also, poetry motivates students to curiously investigate the world and to think more deeply about their own experiences (Perfect, 1999). Poetry has an immense capacity to stimulate empathy, compassion, and humanism (Dunlop, 2007). 
However, the use of poetry left behind in the era of standardized testing. Even though the social studies curricula encourages teachers to enhance their teaching with several activities, the reality of standardized testing has been an obstacle. Teaching students to fill in test bubbles keeps the main priority amongst teachers because test scores are argued to be only determinant of academic achievement (Stovall, 2006). It seems that not only teachers but also policymakers, parents and other stake holders forgot the main purpose of education.

Current elimination of visual and performing arts in public school curricula deny young people access to forms of expression. If we understand education to take place within and beyond the ideological space of the traditional school setting with docile students and didactic instructors, it behooves us to engage and support the spaces young people find relevant to their lives (Stovall, 2006, p.79).

There are strong relationship between literacy and democratic ideals (Greene, 1988). Indeed, literacy supports social studies by providing enormous data for cultivating civic responsibility and social justice for students (Ciardiello, 2010). For instance, poetry played considerable role in supporting human rights advocacy, speaking across differences, hope, beauty (Dunlop, 2007), and protesting inequality and social justice (Ciardiello, 2010).

As Banks and Banks (1999) mentioned, students can learn civic responsibility from relevant case studies of people involved in democratic practices. Providing more personal case studies that related social studies aims in the textbooks assists teachers to use these samples as steppingstones to teach democratic ideals.

Integrating poetry in the social studies provides a new aspect of understanding of what it means to interpret and to know. Indeed, interactive reading of poetry promotes critical thinking skills (Wallace-Jones, 1991), creativity, imagination, and sophisticated thinking (Dunlop, 2007). In addition, integrating poetry into teaching-learning process helps students to become better readers and active listeners (Jensen, 1996). The use of poetry in the social studies also helps students to engage issues such as understanding of other cultures; then assist engagement with these cultures (Lishan \& Hermsen, 2007). Furthermore, integrating poetry increase students' ability to accurately assess situations and people around them.

The use of poetry in social studies education is not common in Turkey. On contrary, the use of poetry to illustrate some geographic concepts has been a long tradition in some western countries such as UK (Donaldson, 2001). Turkish teachers are required to apply centrally designed curriculum and use distributed textbooks for their instruction by National Ministry of Education because of highly centralized education system. They also are checked on a regular basis by NME inspectors to control teachers' compliance with the standard curriculum (Yildirim, 1997). 


\section{Purpose of the Paper}

Many scholars have linked poetry and education in the last decades (Connor-Green, Murdoch, Paul \& Young, 2005; Furman, 2004; Wiseman, 2011). However little of this work has been done within social studies especially in Turkey. Therefore, the purpose of this paper is to investigate the use of poetry in the Turkish social studies textbooks. This paper also examines whose poets have been represented in the textbooks.

\section{Method}

This study aimed to examine the use of poetry in Turkish social studies textbooks. Therefore, the authors chose document analysis as a qualitative research method for data collection. Researchers can obtain rich and robust data for their study through qualitative research strategies such as observation, interview, and document analysis (Glesne, 1999). Document analysis is accepted as an established research method that has been applied to make valid and reliable inferences using texts (Krippendorff, 2004). Documentary analysis concentrate on institutional records or artifacts produces or contained in the setting under study. Curriculum plans, syllabuses, journals, and textbooks are some examples of educational documents (Chism \& Banta, 2007). Researchers can get access to written materials that offer them the significant information to deepen the subject (Glesne, 1999). According to Yin (2009), researchers can study the signs and symbols in documents to investigate the meanings attached to them through document analysis. Social studies textbooks used in the study were accessed through Instruction and Pedagogy Committee's website.

\section{Findings}

In Turkey, Instruction and Pedagogy Committee tests the appropriateness of the textbooks to the curriculum, and National Ministry of Education, approves textbooks that support the curricula. In this highly centralized educational system, the National Ministry of Education also distributed these textbooks to each student for free. This meant that NME has absolute control ever course materials. (Childress, 2001)

\section{$4^{\text {th }}$ Grade Social Studies Textbook}

The content of the $4^{\text {th }}$ grade social studies textbooks depend on the both curriculum and the author's choice of material to include in the book. Instruction and Pedagogy Committee assigned specific teachers and academics to write the $4^{\text {th }}$ grade social studies textbooks. The textbooks also published by NME printing office.

$4^{\text {th }}$ grade social studies textbook consisted of 204 pages and seven themes that was proposed in the curriculum. Instruction and Pedagogy Committee accepted the book as a textbook in 06.14.2017 and published 1.307.737 of them. The textbook started with Turkish flag and 
national anthem as well as other textbooks. This showed that textbooks are still used as tools of nation building.

There are only three poems in the $4^{\text {th }}$ grade social studies textbook. The first one is used in the first theme 'Individual and Society'. The authors provide news and poem about diversity and have students to rewrite written poem. However, there is no sign or instruction about interactive reading of the poem.

I wish children in my country

And all other children in the world

Laugh and play like today

Be brothers in pain and joy

and peace songs play

The second poem is also used in the same theme. This poem is used to mention that people can express their ideas and emotions in various ways such as poems, paintings and writings. The second poem is about human.

Bride-faced daisies are

Beautiful decoration of the prairie

There is more beautiful flower

Which is smiling human face

The last poem is used in the third theme, People, Place, and Environments to illustrate the nature of Şavşat, a district of Artvin province in the Black Sea region. This poem describe the geographic structure of Şavşat, illustrate the situation of this town in four season.

\section{$5^{\text {th }}$ Grade Social Studies Textbook}

Instruction and Pedagogy Committee assigned the same teachers and academics to write the $5^{\text {th }}$ grade social studies textbooks. $5^{\text {th }}$ grade social studies textbook consisted of 204 pages and seven themes that was proposed in the curriculum. Instruction and Pedagogy Committee accepted the book as a textbook in 06.14.2017 and published 1.307.737 of them. The textbook started with Turkish flag and national anthem as well as other textbooks.

The first and second poems are used in the second theme, Culture and Heritage. The first poem Burçak Tarlası 'Vetch Field' is a sample of Turkish folkloric tune, Türkü. In this part of textbook, the authors first explained Türkü as combination of the distinct cultural values of Turkish people. The authors also stated that love, migration, separation, longing are represented through Türkü.

I woke up in the morning to the sound of ezan (call of prayer) It isn't the sound of ezan, it is mourning of vetch pitching my dear, Look at that man, how many fields he has.

Oh girl, how hard it is to pick up vetch, 
How hard it is to be a bride in the vetch field

I woke up in the morning and boil some milk

I spilled milk's mousse on the floor my dear

I lost my mind in the fetch field.

The second poem is also placed in the same theme. The authors provided brief information about the history of tea in Turkey and gave a poem as an example of literature. The poet is a TV presenter who is explicitly supports the ruling party. His poem is about tea addiction.

The last poem, placed in the Active Citizenship theme as a part of symbols of sovereignty and independence. The name of poem is 'Flag', which is written by a famous nationalist poet Arif Nihat Asya. This poem and others showed that patriotic fervor continued to be a prominent feature of social studies textbooks.

O the scarlet white adornment of blue sky

The bridal gown of my sister, the shroud of our martyrs!

O our colors! Incandescent and luminous, rippling in the wind

I've read your saga, I'll write your legend

I will dig his mound whoever looks to you

Not through eyes of mine,

I will mar the nest of any creature of the air

That flies by without salute hail-should it dare

$6^{\text {th }}$ Grade Social Studies Textbook

The content of the $6^{\text {th }}$ grade social studies textbook was written by a private company and it passed the Instruction and Pedagogy Committee's evaluation. $6^{\text {th }}$ grade social studies textbook consisted of 191 pages and seven themes that was proposed in the curriculum. Instruction and Pedagogy Committee accepted the book as a textbook in 09.12.2013 for five years. The textbook started with Turkish flag and national anthem as well as other textbooks.

There is only one poem in the $6^{\text {th }}$ grade social studies textbook. This poem was used in the explanation of one Turkish celebration, henna night. Henna night is one of the most important piece of wedding ceremonies. Bride's last night at her father's house, the sorrows sang with this poem.

Don't let them build a home in the high hills

Don't let them give girls as bride to faraway countries

Don't let them to disdain the mother's one and only

Let the flying birds sense this

I miss my mother

Both my mother and my father 
I miss my village.

I wish my father had a horse so he

Would ride it to come to me

I wish my mother had a sail so she'd set

It to come to me

I wish my siblings had known my address

So they'd come to me

\section{$7^{\text {th }}$ Grade Social Studies Textbook}

$7^{\text {th }}$ grade social studies textbook consisted of 206 pages and seven themes that was proposed in the curriculum. Instruction and Pedagogy Committee accepted the book as a textbook in 02.10.2017 and the textbooks were published by National Ministry of Education. The textbook started with Turkish flag and national anthem as well as other textbooks.

There are only two poems in the $7^{\text {th }}$ grade social studies textbook. The first poem was used in the $5^{\text {th }}$ theme, Economy and social life. The theme started with the importance of soil for human life. The authors used one of the most eminent Turkish poet Aşık Veysel's poem (Black Soil) to explain the role of soil in human life.

It gave sheep, it gave lamb, it gave milk

It gave food, it gave bread, it gave meat

When you didn't peck up the ground, it gave less

My faithfull beloved is black soil.

If I look up in the sky, I breath

If I look down to the earth, I have others pray

Where will I stay if I leave it

My faithfull beloved is black soil.

The last one is Mehmet Akif's, who is Ottoman-born Turkish poet and author of Turkish national anthem, poem about Gallipoli war. This poem was written for Turkish citizens to remind Turkish soldiers' heroism during the war.

What is bosphorus War? Is there an equivalent to it in the world

Four or five of the most dense armies are pressing

In order to go to Marmara finding a way through the hill

To a very small land besieged by many navies

Old world, new world, all the nations of men

They are boiling like sand, Is it Armegeddon?, truly it is

Faces are different, languages, skins are colorful

There is a simple thing obvious: wildnesses are equal

The thunderbolts of bombs are going down through the brains of every shelter 
They go out the chest of those brave soldiers

Sky is bringing down death, earth is spewing out death

What a terrible blizzard it is, wreck of men is thrown into the air

Head, eye, body, leg, arm, chin, finger, hand, foot

They hail onto ridges, valleys

\section{Conclusion and Recommendation}

The process of determining textbook needs, commissioning, approving and distributing showed a very highly centralized education system in Turkey. While several reforms have occurred in the Turkish education system in the last decades, much needs to be done to enhance teachinglearning process in the social studies education as well as other fields. For instance, National Ministry of Education and Instruction and Pedagogy Committee should consider and implement recent pedagogical and theoretical insights such as the reading and writing of poetry.

The results showed that very few poems were used in the social studies textbooks. The finding of the study revealed that poems in the $4^{\text {th }}$ grade textbooks relate to topics that were interest to students the nature and humanism. Poem about Şavşat, described the beauty of Turkish homeland in the four seasons. Vetch Field poem in the $5^{\text {th }}$ grade social studies textbook, described a bride who has to work in the field. This poem seems to be written for girls since the language indicates 'girls' several times. It emphasizes how hard to be a bride in the vetch field. Remaining poems were used to promote students' patriotic values. These poems emphasizes flag, homeland, heroism etc.

Global connection is the theme that was placed in the all social studies textbooks. One of the main aims of this theme is providing a perspective about social justice, empathy, prejudice and discrimination. Poetry played a major role in protesting social justice, prejudice and discrimination (Ciardiello, 2010). Providing poems about these topics helps creating civic awareness and democratic citizenship building (Lee, 2008). However, Turkish social studies textbooks fail to use poems that address social justice, empathy, prejudice and discrimination. There are several online sources for teachers to find appropriate poems for their classroom (see The Academy of American Poets (www.poets.org), The Poetry Archive (http://www.poetryarchive.org/poetryarchive/home.do), Favorite Poem Project (http://www.favoritepoem.org/, National Council of Teachers of English (NCTE) web site http://www.ncte.org ). These websites provide a number of resources including audio archives and lesson plans. On the other hand, there is no this kind of websites for teachers in Turkey. Creating a website that host ageappropriate poems and lesson plans for K-12 assists teachers to create more art-based classroom. 
In addition, having students to write poems enable the deep interest into a specific subject and this engagement leads to greater creative expression (Richardson, 1964). It also helps students to enter the lives and times of real historical people and events (Galt, 1992). Therefore, more poems should be presented in the social studies textbooks to enhance the curriculum and teaching-learning process. Students should be encouraged to read poetry for pleasure instead of exam material.

\section{References}

Apple, M. W. (2004). Ideology and curriculum. New York: Routledge.

Arp, T. (1997). Perrine's Sound and Sense: An Introduction to Poetry. Fort Worth, TX: Hardcourt Brace College Publishers.

Banks, J.A., \& Banks, C.A.M. (1999). Teaching strategies for the social studies: Decision-making and citizen action (5th ed.). New York: Longman.

Barr, H. (1997). Defining social studies. Teachers and Curriculum, 1, 6-12.

Chism, N.V.N. \& Banta, T.W. (2007). Enhancing institutional assessment efforts through qualitative methods. New Directions for Institutional Research, 136, 15-28.

Ciardiello, A. V. (2010). Talking walls: Presenting a case for social justice poetry in literacy education. The Reading Teacher, 63(6), 464-473.

Cole F.L. (1988) Content analysis: process and application. Clinical Nurse Specialist, 2(1), 53-57.

Crocco, M. S. (2004). Dealing with the difference in the social studies: A historical perspective. International Journal of Social Education, 18(2), 106-120.

Donaldson, D. P. (2001) Teaching Geography's four traditions with Poetry. Journal of Geography, 100(1), 24-31.

Dunlop, R. (2007). Human music: A case for teaching poetry in dark times. In L. Bresler (Ed.), International Handbook of research in arts education (pp. 1253-1270), Dordrecht. Netherlands: Springer.

Elo, S., \& Kyngas, H. (2008). The qualitative content analysis process. Journal of Advanced Nursing, 62(1), 107-115.

Galt, M. F. (1992). The story in history: Writing your way into the American experience. New York: Teachers \& Writer's Collaborative. 
Tarman \& Kilinc, Poetry in the Social Studies Textbooks in Turkey

Glesne, C. (1999). Becoming qualitative researchers: An introduction. New York: Longman.

Gözütok, F. D. (2008). Curriculum development in Turkey. In W. F. Pinar (Ed.) International handbook of curriculum research (pp. 607-622). New Jersey: Lawrence Erlbaum Associates Publishers.

Greene, M. (1988). The dialectic of freedom. New York: Teachers College Press.

Jensen, T. (1996). Ways of experiencing poetry and acquiring poetic knowledge in the secondary school. In L. Thompson (Ed.), The teaching of poetry: European perspectives (pp. 3036). London: Cassell.

Kilinc, E. (2012). Conceptual Learning in Social Studies Classroom: An Analysis of Texas Assessment of Knowledge and Skills (TAKS) Social Studies Questions with and without Concept (Unpublished doctoral dissertation, Texas A\&M University).

Krippendorff, K. (2004). Reliability in content analysis. Human Communication Research, 30(3), 411-433.

Lee, C.D. (2008). Revisiting playing in the dark: The hidden games of racialization in literacy studies and school reform. In S. Greene (Ed.), Literacy as a civil right: Reclaiming social justice in literacy teaching and learning (pp. 151-168). New York: Peter Lang.

Lishan, S. D. \& Hermsen, T. (2007). Later 'in the early world': The changing role of poetry and creative writing in the K-12 classroom. In L. Bresler (Ed.), International Handbook of research in arts education (pp. 623-638), Dordrecht. Netherlands: Springer.

Mauch, J., \& Tarman, B. (2016). A historical approach to social studies laboratory method. Research in Social Sciences and Technology, 1(2), 55-66.

Perfect, K. (1999). Rhyme and reason: Poetry for the heart and head. Reading Teacher, 52(7), 728-737.

Pinar, W. F. (1999). Contemporary curriculum discourses: Twenty years of JCT. New York: Peter Lang.

Pinsky, R. (2007). Gulf music. New York: Farrar, Straus \& Giroux.

Richardson, E. (1964). In the early world. New York: Random House.

Roberts, P. (2008). Contemporary curriculum research in New Zeland. In W. F. Pinar (Ed.) International handbook of curriculum research (pp. 495-516). New Jersey: Lawrence Erlbaum Associates Publishers. 
Tarman \& Kilinc, Poetry in the Social Studies Textbooks in Turkey

Ross, E. W. (2006). The struggle for the social studies curriculum. In E. Wayne Ross (Ed.), The social studies curriculum: Purposes, problems, and possibilities (pp. 17-36), New York, NY: State University of New York Press.

Singer, A. (2005). Strange bedfellows: The contradictory goals of the coalition making war on social studies. Social Studies, 96(5), 199-205.

Slattery, P. (2008). Hermeneutics, Subjectivity, and Aesthetics: Internationalizing the Interpretive Process in U.S. Curriculum Research. In W. F. Pinar (Ed.) International handbook of curriculum research (pp. 651-665). New Jersey: Lawrence Erlbaum Associates Publishers.

Stovall, D. (2006). Urban Poetics: Poetry, Social Justice and Critical Pedagogy in Education. The Urban Review, 38(1), 63-80.

Tarman, B., \& Dev, S. (2018). Editorial: Learning Transformation through Innovation and Sustainability in Educational Practices. Research In Social Sciences And Technology, 3(1), i-ii. Retrieved from http://ressat.org/index.php/ressat/article/view/363

Tarman, B. (2017). Editorial: The Future of Social Sciences. Research in Social Sciences and Technology, 2(2). Retrieved from http://ressat.org/index.php/ressat/article/view/329

Tarman, B. \& Gürel, D. (2017). Awareness of Social Studies Teacher Candidates on Refugees in Turkey, Journal of Social Studies Research, DOI: 10.1016/j.jssr.2016.11.001

Tarman, B. (2016). Innovation and education. Research in Social Sciences and Technology, 1(1), 77-97.

Tarman, B. (2011). Development of Social Studies Curriculum in Turkey and John Dewey's Effect on the Modernization of Turkish Education, International Journal of Progressive Education, (IJPE). February, 7 (1). 45-61.

Tarman, B., Ayas, C. (2011). Comparing Issues Surrounding Turkish and Japanese Textbooks, International Journal of Historical Learning Teaching and Research, Vol (10).1, 67-76 (Sping/Summer 2011).

Tarman, B. \& Acun, I. (2010). Social Studies Education and a New Social Studies Movement, Journal of Social Studies Education Research. 1(1), 1-16.

Threlfall, S. J. (2013). Poetry in action [research]. An innovative means to a reflective learner in higher education (HE). Reflective Practice: International and Multidisciplinary Perspectives, 14(3), 360-367. 
Wallace-Jones, J. (1991). Cognitive response to poetry in 11 to 16 year olds. Educational Review, 43, 25-38.

Weber, R. P. (1990). Basic content analysis. London: Sage.

Yiğit, M , Tarman, B . (2013). Degerler Eğitimimin ilköğretim 4. Ve 5. Sınıf Sosyal Bilgiler Ders Kitaplarindaki Yeri ve Önemi (The Place and Importance of Values Education in 4.th and 5th. Grade Primary School Social Studies Textbooks). Journal of Social Studies Education Research, 4 (2), 79-102. Retrieved from http://dergipark.gov.tr/jsser/issue/19101/202712

Yin, R. (2009). How to do better case studies. In Bickman, L. and Rog, D.J. (Eds), The SAGE Handbook of Applied Social Research Methods (pp 254-282). Thousand Oaks, CA: SAGE Publications Inc. 